\title{
Original
}

\section{Expression of Smooth Muscle Calponin in Proliferative Glomerulonephritis in the Rat}

\author{
Kiyoko Inui, Ashio Yoshimura, Youichi Sugenoya, \\ Susumu Watanabe, Hiroyuki Morita and Terukuni IDEura
}

\begin{abstract}
The basic calponin gene, that encodes an actin-binding protein involved in the regulation of smooth muscle contractility, is specific to smooth muscle differentiation. Basic calponin is expressed by cultured mesangial cells, and localized along the actin filaments. Our previous studies suggested that down regulation of basic calponin correlates with mesangial cell proliferation, implying the involvement of basic calponin in suppressing mesangial cell proliferation. In this study, we examined whether basic calponin is expressed in the glomerulus in anti-Thy 1.1 nephritis rats as an in vivo model for proliferative glomerulonephritis. Basic calponin mRNA and protein were expressed in the proliferative phase of this model, and paralleled $\alpha$-smooth muscle actin expression by mesangial cells. Basic calponin may regulate excessive mesangial cell proliferation in this model. Elucidation of the molecular mechanisms regulating basic calponin expression in mesangial cells will contribute to an understanding of the molecular basis of the glomerular response to injury, which may be useful in the development of therapeutic interventions for human renal diseases.
\end{abstract}

Key words : mesangial cells, calponin, actin-binding protein, smooth musclespecific gene

\section{Introduction}

Glomerular mesangial cells are mesenchyme-derived multipotential cells which undergo phenotypic change as a result of $\alpha$-smooth muscle actin ( $\alpha$ SMA) expression during glomerular inflammation ${ }^{1,2)}$. Phenotypic change of mesangial cells is tightly associated with activation, proliferation, and early response to mediators, and also to the synthesis and release of extracellular matrix protein, chemical mediators and vasoactive substances. Therefore an understanding of the regulation of mesangial cell phenotypic change may provide useful insight into future therapeutic strategies for progressive glomerulonephritis. It may be possible to regulate the phenotypic change of mesangial cells by controlling the expression of smooth muscle-associated genes. There are several contractile proteins associated with phenotypic modulation of vascular smooth muscle cells. Calponin is one such protein and is the focus of this study. Calponin was originally isolated as an actin-binding protein involved in the regulation of smooth muscle contraction ${ }^{2-4)}$. Three 
distinct mammalian calponin genes have been identified and include basic calponin (calponin h1), neutral calponin (calponin h2), and acidic calponin ${ }^{5-7)}$. Expression of the basic calponin gene specifically marks smooth muscle cell differentiation ${ }^{3,8-11)}$, while the neutral and acidic calponin genes are expressed in both smooth muscle and non-smooth muscle cells ${ }^{6,7)}$. Basic calponin is capable of inhibiting actomyosin ATPase activity ${ }^{12,13)}$, induces actin polymerization at low ionic strength and inhibits depolymerization of actin filaments ${ }^{14)}$. Overexpression of basic calponin in cultured smooth muscle cells, fibroblasts and tumor cells suppresses their proliferation ${ }^{15,16)}$. Taken together, these observations suggest that, in addition to the regulation of smooth muscle contractility, basic calponin may control cytoskeleton formation and may therefore influence cytokinesis, proliferation and differentiation of cells. In this study, we examined the in vivo expression of basic calponin in a rat model of mesangial proliferative glomerulonephritis induced by the anti-thymocyte monoclonal antibody, anti-Thy 1.1 .

\section{Materials and Methods}

\section{Disease model}

This study was designed to determine whether basic calponin is expressed in the glomerulus in anti-Thy 1.1 induced mesangial proliferative glomerulonephritis in the rat. Thirty Wistar male rats weighing 180 to $200 \mathrm{~g}$ (Nippon Ikagaku Doubutsu, Tokyo, Japan) were fed with standard rat chow (Oriental Yeast Co. Ltd., Tokyo, Japan). The disease was induced in twenty-five rats by a single intravenous injection of anti-Thy 1.1 monoclonal antibody using $2.5 \mathrm{ml} / \mathrm{kg}$ of a $10 \%$ solution (Cedarlane Laboratories Limited, Hornby, Ontario, Canada) as previously described ${ }^{17)}$. At day 2, 4, 7, 12 and 20 following induction of the disease a total of five rats for each time point were sacrificed. The kidneys were removed for histological study, and total RNA was extracted for RT-PCR analysis. As a control five normal rats were sacrificed at day 0 .

\section{Renal morphology and immunohistochemical staining in anti-Thy 1.1 nephritis}

Tissue for light microscopy and immunoperoxidase staining was fixed in methyl Carnoy's solution $^{18)}$ and embedded in paraffin. Four-micrometer sections were stained using the indirect immunoperoxidase method. Primary antibodies included the following: 19A2 (Coulter Immunology, Hialeah, FL, USA), a murine monoclonal antibody against human PCNA, which is an auxiliary protein to DNA polymerase delta that is expressed in late $G_{1}$, peaking during $S$ phase, and extending to the $M$ phase of the cell cycle; an IgG fraction of the murine monoclonal antibody to $\alpha$ SMA (DAKO, Glostrup, Denmark), which has been shown to stain activated mesangial cells in vivo ${ }^{19)}$; and a polyclonal antibody to synthetic carboxyl-terminal peptides (Leu-281-Ala-297) of human basic calponin generated in rabbits ${ }^{20)}$. Quantification of proliferating $\mathrm{PCNA}^{+}$cells was performed by examining biopsies, in a blinded manner, containing more than 20 discrete capillary segments each (range, 20 to 38; mean 26.8 \pm 6.6 ) and recording the number of positive cells per glomerular cross section ${ }^{21)}$. Staining for $\alpha$ SMA and basic calponin was evaluated by grading each glomerulus semiquantitatively as previously described ${ }^{22,23)}$. Enumeration is as follows: 0, diffuse, very weak, or absent mesangial matrix staining and no localized increase of staining; $1+$, diffuse weak mesangial matrix staining with 1 to $25 \%$ of the glomerular tuft showing focally increased staining; $2+, 25$ to $50 \%$ of the glomerular tuft demonstrating 
focal, strong staining; $3+, 50$ to $75 \%$ of the glomerular tuft staining strongly in a focal manner; and $4+,>75 \%$ of the glomerular tuft staining strongly.

\section{RT-PCR analysis of basic calponin mRNA expression in glomeruli}

Glomeruli from all groups of rats were isolated by differential sieving ${ }^{24)}$ and total RNA was extracted using RNAzolB (Cinna/Biotecx Laboratories, Houston, TX, USA) following the manufacturer's instructions as previously reported ${ }^{21,25)}$. Reverse transcription (RT) using $2 \mu \mathrm{g}$ of total RNA was carried out using the reaction mixture of Ready-To-Go You-Prime First-Strand Beads (Amersham Pharmacia LKB Biotechnology, Buckinghamshire, UK) in the presence of $0.2 \mu \mathrm{g}$ of the random hexamer primer. After $60 \mathrm{~min}$ at $37^{\circ} \mathrm{C}, 0.5$ $\mu \mathbf{M}$ of each of the forward and reverse primers, $200 \mu \mathrm{M}$ of dNTP mixture and $2.5 \mathrm{U}$ of Taq DNA polymerase (Life Technologies, Gaithersburg, MD, USA) were added to $8 \mu 1$ of the first-strand reaction mixture. The total volume was adjusted to $50 \mu \mathrm{l}$ with water prior to PCR amplification using 30 cycles of denaturation $\left(94^{\circ} \mathrm{C}, 40 \mathrm{sec}\right)$, annealing $\left(60^{\circ} \mathrm{C}, 30\right.$ sec) and polymerization $\left(72^{\circ} \mathrm{C}, 90 \mathrm{sec}\right)$. Sequences of the forward and reverse primers, and expected products size are as follows:

\section{basic calponin, 671-bp, GAGTGTGCAGCAGAAACTTCAGCC (forward), GTCTGTGCCCAACTTGGGGTC (reverse), \\ glyceraldehyde 3-phosphate dehydrogenase (GAPDH), 731-bp \\ CCCATCACCATCTTCCAGGA (forward), TTGTCATACCAGGAAATGAGC (reverse).}

Linear production of PCR products for calponin and GAPDH was obtained between 25 and 30 cycles. After $1 \%$ agarose gel electrophoresis in the presence of $0.5 \mu \mathrm{g} / \mathrm{ml}$ ethidium bromide, PCR products were revealed by UV irradiation and the image was captured by NIH image analysis (version 1.61). Semiquantitative levels of basic calponin mRNA were normalized to equivalent levels of GAPDH mRNA per sample. Negative controls, including a sample with PCR reagents in the absence of RT reaction mixture, showed no specific signals.

\section{Statistical analysis}

Values were expressed as the mean \pm S.E. Statistical differences were determined using Student's t-test for unpaired samples. Differences were considered statistically significant with $\mathrm{p}<0.05$.

\section{Results}

\section{Expression of basic calponin protein in mesangial proliferative nephritis}

Previous studies using the anti-Thy 1.1 model for mesangial proliferative nephritis showed that mesangial cell proliferation begins at day 2, peaks between day 3 and day 5 , and is resolved by day $14^{18,21,23,26)}$. Proliferation of $\mathrm{PCNA}^{+}$cells was consistent with this pattern, with a marked increase in the number of PCNA $^{+}$cells at day $2(15.1 \pm 0.8)$, day 4 (28.5 $\pm 3.7)$ and day $7(9.1 \pm 1.1)$ compared with normal rats (day $0,1.1 \pm 0.1)$ (Fig. 1). Mesangial cell proliferation in rat glomerulonephritis is associated with a distinct phenotypic change in which mesangial cells assume smooth muscle cell characteristics. Therefore, de 

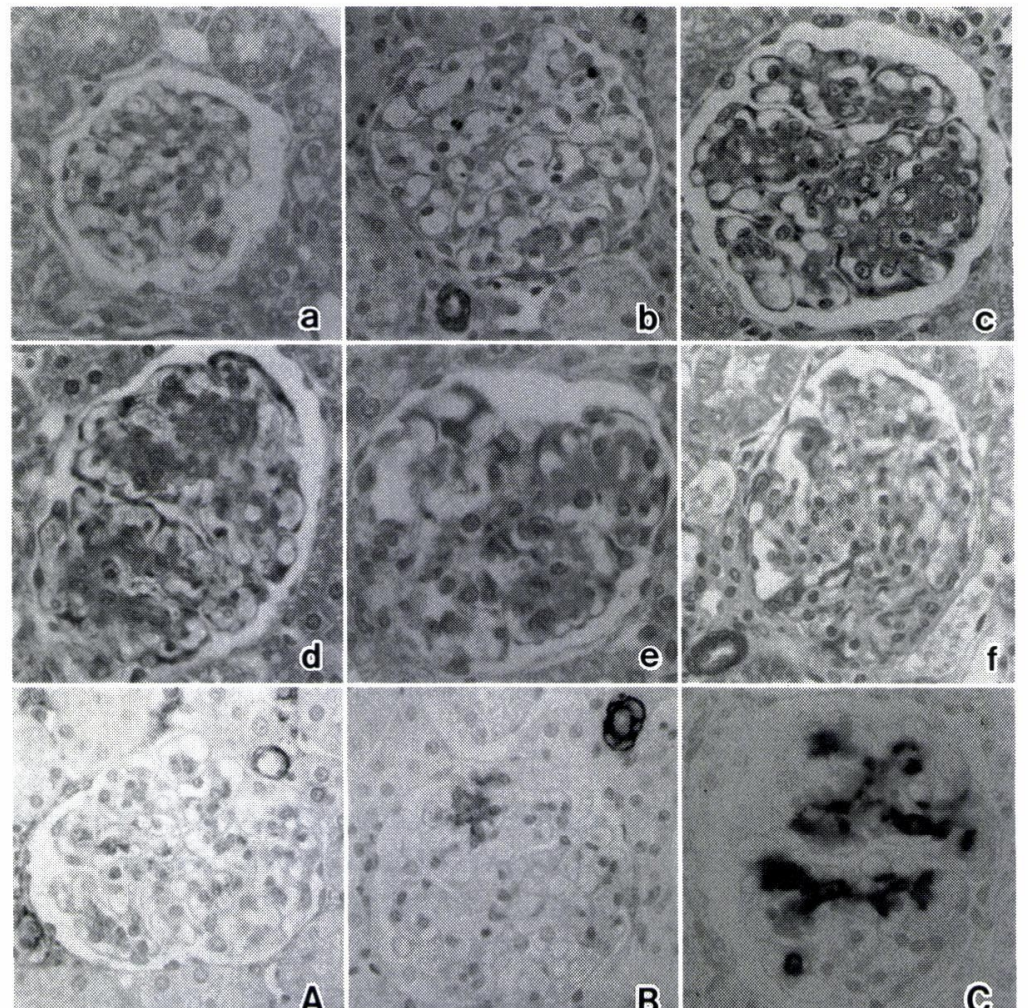

A
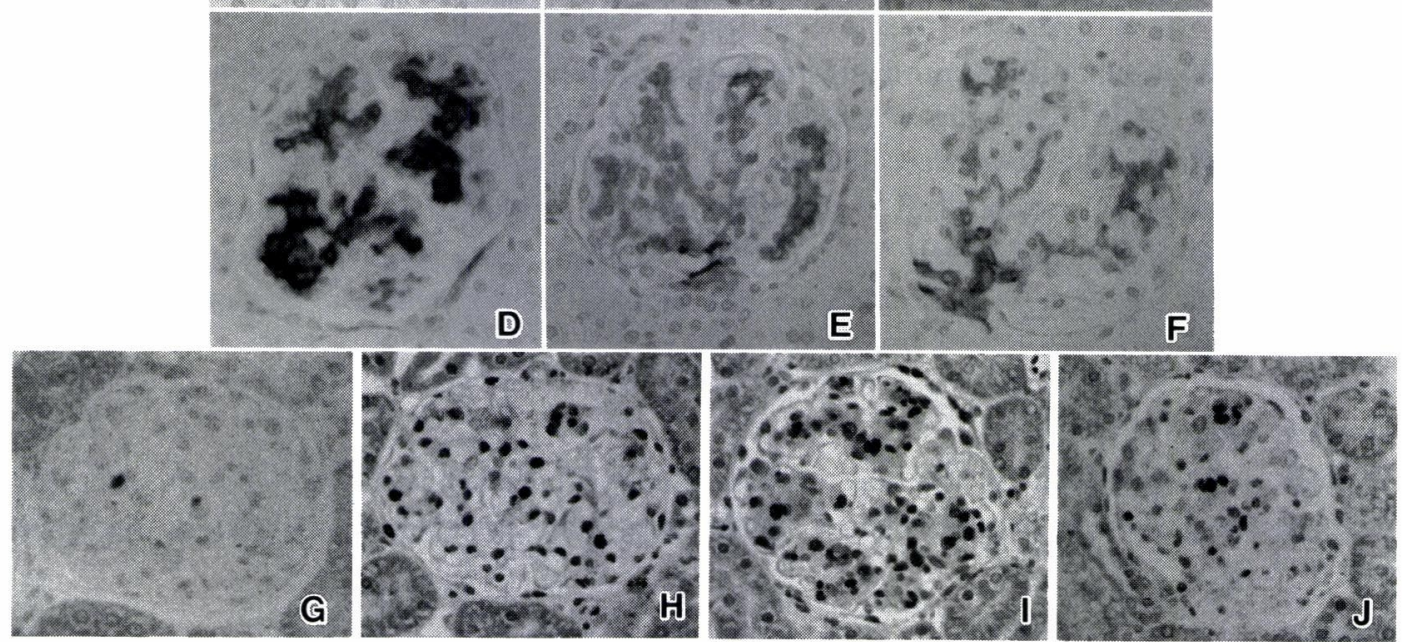

Fig. 1. Immunohistochemistry for basic calponin (a-f), $\alpha$-smooth muscle actin ( $\alpha$ SMA) (A-F) and PCNA (G-J) in normal and anti-Thy 1.1 nephritis rats. Positive staining for basic calponin was observed in smooth muscle cells of arteries in renal tissue from both normal and diseased rats. However, there was almost no positive staining for basic calponin in the glomerulus in rats of day 0 (a) and day 2 (b), respectively. The staining intensity was greatest for the basic calponin protein in the mesangium after day 4 (c). Basic calponin proteins levels then decreased. $\alpha$ SMA expression was observed only in the arterial wall at day $0(\mathbf{A})$, but after day 2 (B) expression had increased. A marked increase in the number of PCNA ${ }^{+}$cells was observed from day 2 to day 7 . Immunoperoxidase, $\times 400$, a-f : basic calponin, A-F : $\alpha$ SMA, G-J : PCNA; a, A and G : day $0 ; \mathrm{b}, \mathrm{B}$ and $\mathrm{H}$ : day 2 ; c, C and I : day $4 ; \mathrm{d}, \mathrm{D}$ and $\mathrm{J}$ : day 7 ; e and $\mathrm{E}$ : day 12 ; f and $\mathrm{F}$ : day 20 (after disease induction, respectively). 

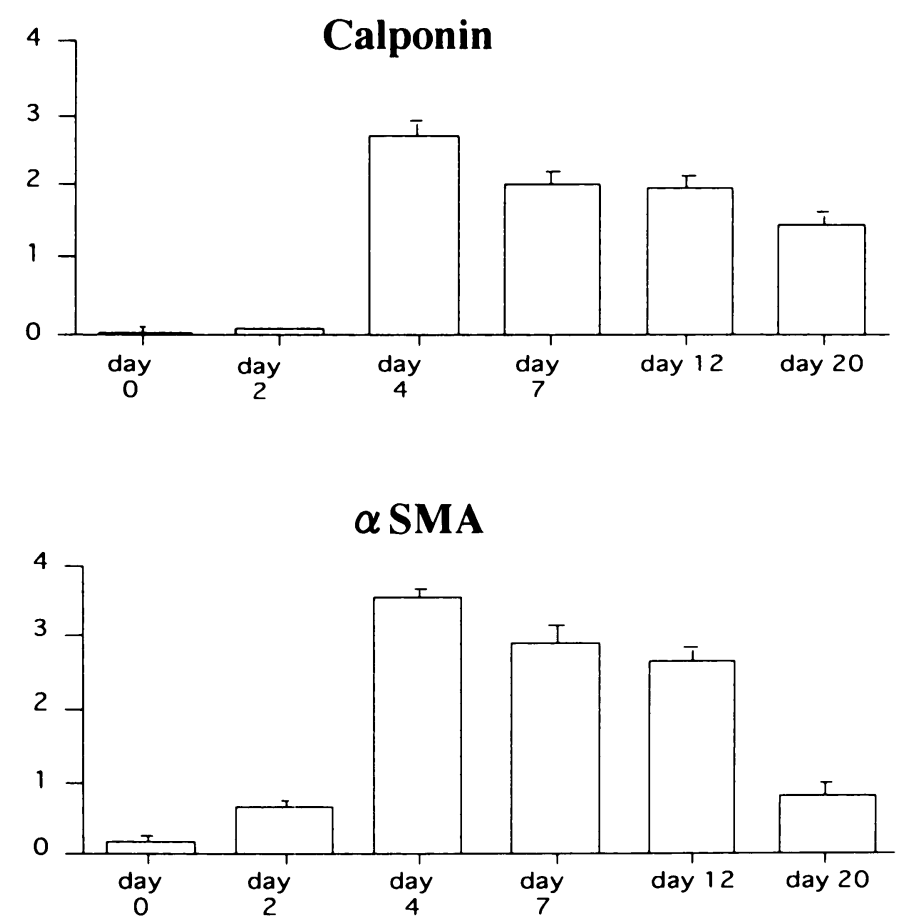

Fig. 2. Staining score for basic calponin and $\alpha$-smooth muscle actin ( $\alpha$ SMA) in normal and anti-Thy 1.1 nephritis rats. Staining scores for basic calponin were as follows; day $0: 0 \pm 0.1$, day $2: 0.1 \pm 0$, day $4: 2.6 \pm 0.3$, day $7: 2.0 \pm 0.3$, day $12: 1.9 \pm 0.3$, day $20: 1.5 \pm 0.2$. The highest levels of staining for basic calponin occurred at day 4. The staining scores for $\alpha$ SMA were, day $0: 0.2 \pm 0.1$, day $2: 0.7 \pm 0.1$, day 4 : $3.5 \pm 0.1$, day $7: 2.8 \pm 0.4$, day $12: 2.6 \pm 0.3$, and day $20: 0.8 \pm 0.2 . \alpha$ SMA expression paralleled basic calponin expression and was highest at day 4 .

novo $\alpha$ SMA expression is a useful marker for mesangial cell activation ${ }^{27)}$. An increase in $\alpha$ SMA expression was detected by day 2 (staining score $=0.7 \pm 0.1$ ) after disease induction, followed by a further increase at days 4,7 and 12 (staining score : $3.5 \pm 0.1$ at day 4, 2.8 \pm 0.4 at day $7,2.6 \pm 0.3$ at day 12) (Fig. 1 and Fig. 2). Positive staining for basic calponin was observed in smooth muscle cells of arteries in renal tissue from both normal and diseased rats, however there was almost no positive staining for basic calponin in the glomerulus at day 0 (staining score $=0 \pm 0.1$ ) and day 2 (staining score $=0.1 \pm 0$ ). Increased expression of basic calponin protein was also observed in the mesangium after day 4 when staining intensity was greatest (staining score $=2.6 \pm 0.3$; Fig. 1 ) and was found to decrease thereafter (2.0 \pm 0.3 at day $7,1.9 \pm 0.3$ at day $12,1.5 \pm 0.2$ at day 20) (Fig. 1 and Fig. 2). Thus, expression of basic calponin and $\alpha$ SMA in the glomerulus were greatest at the peak of mesangial cell proliferation.

\section{Expression of basic calponin $m R N A$ in mesangial proliferative nephritis}

Basic calponin mRNA expression in the glomerulus was analysed by RT-PCR. There was no basic calponin mRNA expression at day 2 or day 0 . Increased gene expression was greatest at day 4 and decreased gradually thereafter in parallel with changes in the protein 

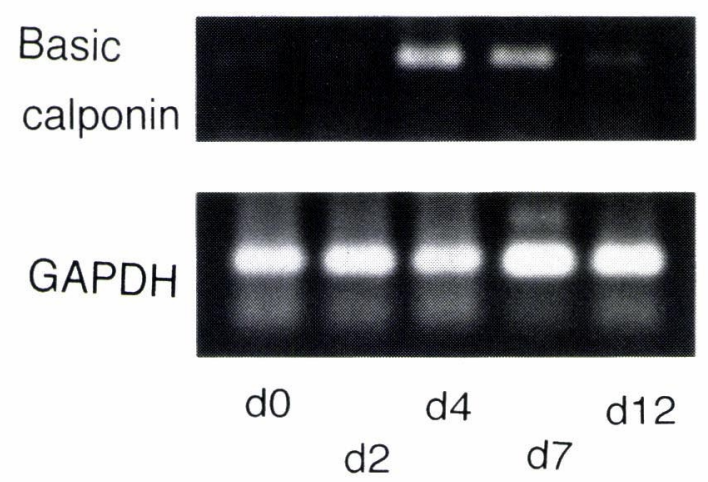

Fig. 3. Basic calponin mRNA expression in the glomerulus analyzed by RT-PCR. There was only faint basic calponin mRNA expression at day 2 and day 0 . Increased gene expression was at a maximum level at day 4 and decreased gradually thereafter. For each sample semiquantitative levels of basic calponin mRNA were normalized using equivalent levels of GAPDH mRNA. Expression ratios were 11.80 (day 4): 6.59 (day 7): 1.82 (day 12$)$.

level as shown by immunostaining. The ratio of basic calponin mRNA compared to normal rats was 11.80 (day 4), 6.59 (day 7) and 1.82 (day 12), (Fig. 3). There was no gene expression in negative control samples.

\section{Discussion}

Phenotypic modulation and dedifferentiation of mesangial cells is a characteristic feature of glomerular diseases ${ }^{28)}$. Expression of $\alpha$ SMA is a marker for activation and phenotypic modulation of mesangial cells ${ }^{1}$. Previous studies demonstrate that a core sequence of the

$\alpha$ SMA promoter, containing two highly conserved CArG box motifs, is essential for serum-stimulated $\alpha$ SMA expression in rat mesangial cells ${ }^{29)}$. We have already reported that basic calponin, a smooth muscle-differentiation specific gene, is expressed at a high level, and localized along actin filaments in cultured mesangial cells ${ }^{30}$. Also, we have shown that treatment with anti-glomerular basement membrane antibody induces more severe nephritis in basic calponin knockout mice than in wild type mice based on urinary protein excretion, glomerular cellularity, expression of PCNA, crescentic formation and interstitial cellularity ${ }^{30}$. We therefore speculate that down-regulation of basic calponin correlates with promotion of mesangial cell proliferation, and that basic calponin suppresses mesangial cell proliferation. This is consistent with the finding that overexpression of basic calponin in smooth muscle cells, fibroblasts and tumor cells inhibits their proliferation ${ }^{15,16)}$. As a next step, investigation of basic calponin expression in the glomerulus in glomerulonephritis in vivo is necessary. Using the anti-Thy 1.1 rat model for nephritis we showed that basic calponin mRNA and protein are expressed in the proliferative phase of glomerulonephritis and parallel the expression of $\alpha$ SMA by mesangial cells. Cultured human mesangial cells that overexpress basic calponin show reduced PDGF-BB induced proliferation, and excessive mesangial cell proliferation in anti-Thy1.1 nephritis is suppressed in basic calponin transgenic rats ${ }^{31}$. Therefore, expression of basic calponin in mesangial cells may function as an intrinsic regulator in proliferative glomerular injuries. Apoptosis is important in the 
progression of anti-Thy1.1 nephritis, however the relationship between calponin expression and mesangial cell apotosis is unknown. Elucidation of the molecular mechanism regulating basic calponin expression in mesangial cells will contribute to an understanding of the molecular basis of the glomerular response to injury, and may be useful in the development of therapeutic interventions for human renal diseases.

\section{Acknowledgements}

The authors would like to thank all members of the Division of Nephrology of Showa University Fujigaoka Hospital for their support in this study.

\section{References}

1) Johnson RJ, Floege J, Yoshimura A, Iida H, Couser WG and Alpers CE: The activated mesangial cell : a glomerular "myofibroblast"? J Am Soc Nephrol 2 : S190-S197 (1992)

2) Takahashi K, Hiwada $\mathbf{K}$ and Kokubu $\mathrm{T}$ : Vascular smooth muscle calponin : a novel troponin T-like protein. Hypertension 11 : 620-626 (1988)

3) Gimona M, Herzog M, Vandekerckhove J and Small JV : Smooth muscle specific expression of calponin. FEBS Lett 274 : 159-162 (1990)

4) Winder SJ and Walsh MP: Smooth muscle calponin: inhibition of actomyosin MgATPase and regulation by phosphorylation. J Biol Chem 265 : 10148-10155 (1990)

5) Strasser P, Gimona $M$, Moessler H, Herzog $M$ and Small JV: Mammalian calponin : identification and expression of genetic variants. FEBS Lett 330 : 13-18 (1993)

6) Masuda H, Tanaka T, Takagi M, Ohogami K, Sakamaki T, Shibata N and Takahashi K : Molecular cloning and characterization of human non-smooth muscle calponin. $J$ Biochem 120 : 415-424 (1996)

7) Applegate D, Feng W, Green RS and Taubman MB: Cloning and expression of a novel acidic calponin isoform from rat aorta vascular smooth muscle. J Biol Chem 269 : 10683-10690 (1994)

8) Takahashi $\mathrm{K}$ and Nadal-Ginard B : Molecular cloning and sequence analysis of smooth muscle calponin. $J$ Biol Chem 266 : 13284-13288 (1991)

9) Duban J-L, Gimona M, Scatena M, Satore S and Small JV: Calponin and SM22 as differentiation markers of smooth muscle: spatiotemporal distribution during avian embryonic development. Differentiation 55 : 1-11 (1993)

10) Miano JM and Olsern EN : Expression of the smooth muscle cell calponin gene marks the early cardiac and smooth muscle cell lineages during mouse embryogenesis. J Biol Chem 271 : 7095-7103 (1996)

11) Samaha FF, Ip HS, Morrisey EE, Seltzer J, Tang Z, Solway J and Permacek MS : Developmental pattern of expression and genomic organization of the calponin-h1. J Biol Chem 271 : 395-403 (1996)

12) Gimona $\mathbf{M}$ and Small JV: Calponin. In: Biochemistry of smooth muscle contraction M. Baraney (ed.), Academic Press, New York: pp. 91-103 (1995)

13) Winder SJ and Walsh MP: Calponin. Curr. Topics Cell Regul 34 : 33-61 (1996)

14) Kake T, Kimura S, Takahashi $K$ and Maruyama $K$ : Calponin induces actin polymerization at low ionic strength and inhibits depolymerization of actin filaments. Biochem J 312 : 587-592 (1995)

15) Jiang Z, Grange RW, Walsh MP and Kamm KE: Adenovirus-mediated transfer of the smooth muscle cell calponin gene inhibits proliferation of smooth muscle cells and fibroblasts. FEBS Lett 413 : 441-445 (1997)

16) Horiuchi A, Nikaido T, Taniguchi $S$ and Fujii $S$ : Possible role of calponin hl as a tumor suppressor in human uterine leiomyosarcoma. Natl Cancer Inst 91 : 790-796 (1999)

17) Yoshimura A, Inui K, Nemoto T, Uda S, Sugenoya Y, Watanabe S, Yokota Y, Taira T, Iwasaki S and Ideura $\mathrm{T}$ : Simvastatin suppresses glomerular cell proliferation and macrophage infiltration in rats with mesangial proliferative nephritis. J Am Soc Nephrol 9 : 2027-2039 (1998)

18) Johnson RJ, Garcia RL, Pritzl P and Alpers CE : Platelets mediate glomerular cell proliferation in immune complex nephritis induced by anti-mesangial antibodies in the rat. Am J Pathol $136: 369-374$ (1990)

19) Alpers CE, Hudkins KL, Gown AM and Johnson RJ : Enhanced expression of "muscle-specific" actin glomerulonephritis. Kidney Int 41 : 1134-1142 (1992)

20) Yoshikawa H, Taniguchi, S, Yamamura H, Mori S, Sugimoto M, Miyado K, Nakamura K, Nakao K, Katsuki $\mathbf{M}$, Shibata $\mathbf{N}$ and Takahashi $\mathrm{K}$ : Mice lacking smooth muscle calponin display increased bone formation that is associated with enhancement of bone morphogenetic protein responses. Genes Cells $3: 685-695$ (1998)

21) Yoshimura A, Iwasaki S, Inui K, Ideura T, Koshikawa S, Yanagisawa $M$ and Masaki $T$ : Endothelin-1 and endothelin B type receptor are induced in mesangial proliferative nephritis in the rat. Kidney Int 48 : 12901297 (1995) 
22) Floege J, Johnson RJ, Gordon K, Iida H, Pritzl P, Yoshimura A, Campell C, Alpers CE and Couser WG : Increased synthesis of extracellular matrix in mesangial proliferative nephritis. Kidney Int $40: 477-488$ (1991)

23) Yoshimura A, Gordon K, Alpers CE, Floege J, Pritzl P, Ross R, Couser WG, Bowen-Pope DF and Johnson RJ : Demonstration of PDGF B-chain mRNA in glomeruli in mesangial proliferative nephritis by in situ hybridization. Kidney Int $40:$ 470-476 (1991)

24) Bradley GM and Benson ES : Examination of the urine. In : Todd-Sanford Clinical Diagnosis by Laboratory Methods, Davidson I and Henry JB (Eds.), Saunders, Philadelphia, pp 74 (1974)

25) Floege J, Burns MW, Alpers CE, Yoshimura A, Pritz P, Gordon K, Seifert RA, Bowen-Pope DF, Couser WG and Johnson RJ : Glomerular cell proliferation and PDGF expression precede glomerulosclerosis in the remnant kidney model. Kidney Int 41 : 297-309 (1992)

26) Iida H, Seifert R, Alpers CE, Gronward RGK, Philips PE, Pritzl P, Gordon K, Gown AM, Ross R, Bowen-Pope DF and Johnson RJ : Platelet-derived growth factor (PDGF) and PDGF receptor are induced in mesangial proliferative nephritis in the rat. Proc Natl Acad Sci USA 88: 6560-6564 (1991)

27) Johnson RJ, Iida H, Alpers CE, Majesky MW, Schwartz SM, Pritzl P, Gordon AM and Gown AM : Expression of smooth muscle cell phenotype by rat mesangial cells in immune complex nephritis. $J$ Clin Invest $87: 847-858$ (1991)

28) Johnson RJ : The glomerular response to injury: progression or resolution? Kinney Int 45 : $1769-1782$ (1994)

29) Simonson MS, Walsh K, Kumar CC, Bushel P and Herman WH: Tow proximal CArG elements regulate SM $\alpha$-actin promoter, a genetic marker of activated phenotype of mesangial cells. Am J Physiol 268: F 760F 769 (1995)

30) Sugenoya Y, Yoshimura A, Yamamura H, Inui K, Morita H, Yamabe H, Ueki N, Ideura T and Takahashi $\mathrm{K}$ : Smooth muscle calponin in mesangial cells: Regulation of expression and a role in suppressing glomerulonephritis. J Am Soc Nephrol 13:322-331 (2002)

31) Sugenoya Y, Yoshimura A, Inui K, Yamamura H, Morita H, Ideura T and Takahashi $K$ : Regulation of excessive mesangial cell proliferation by overexpression of smooth muscle calponin. J Amer Soc Nephrol 11 : 499A (2000)

[Received November 13, 2001 : Accepted January 8, 2002] 